\title{
Toward a Competitive Pakistan: The Role of Industrial Policy
}

\section{Irfan ul Haque*1}

\begin{abstract}
This paper's basic premise is that an improvement in Pakistan's export performance is crucial to raising economic growth. After examining the reasons generally given for Pakistan's poor export performance, we conclude that the country's very slow productivity growth was the single most important factor that hurt competitiveness. We argue that a coherent and articulated industrial policy is required to overcome this disadvantage. While the experience of the East Asian economies offers useful lessons, Pakistan's policy must accord with its own conditions, which are, in many ways, different. The formulation of industrial policy should involve key stakeholders, particularly the private sector. The paper identifies certain factors that should underpin the new industrial policy, notably the changed basis of international specialization and rules governing world trade.
\end{abstract}

Keywords: Pakistan, East Asia, industrial policy, export performance, productivity

JEL classification: F43, L59.

\section{Introduction}

Pakistan's balance of payments (BOP) has been an enduring constraint to its economic growth. Other factors-natural disasters and political instability in particular-have also been important, but they have not had a deterministic or consistent impact on the country's economic performance. This paper's basic premise is that, while occasional surges in the import bill or sudden declines in foreign inflows may have been proximate causes of past BOP crises, low export growth has remained a persistent drag on economic growth. Thus, improving the country's export performance to match that of other rapidly growing economies is pivotal to achieving and sustaining accelerated economic growth.

\footnotetext{
* Special Advisor for Financing for Development, South Centre, Geneva.

${ }^{1}$ The author wishes to thank Rafia Zafar for her help in compiling and analyzing the data used in this study. He also wishes to thank Rashid Amjad, Shakil Faruqi, Khalil Hamdani, and Shahid Kardar for reading an earlier draft of the paper and for their helpful suggestions.
} 
Why export growth must be taken as a dominant concern in policymaking is elucidated in the next section. We show that unsatisfactory export performance, rather than untoward rises in the import bill, has generally been the underlying cause of Pakistan's unsustainable trade deficits. Section 3 explores the "pathology" of the export failure, which is linked, directly or indirectly, to the failure of a thriving, internationally competitive industry to arise. The factors that have hampered industry have also affected the growth of agricultural or services sector exports. This section is followed by a discussion of the form of industrial policy that could help Pakistan become internationally competitive and realize more secure and rapid export growth. The final section concludes the study.

\section{Export Performance: The Dominant Concern}

Figure 1 traces the changes in Pakistan's trade balance as a percentage of GDP since 1980 along with the corresponding data for four other countries in the region: Bangladesh, China, India, and Indonesia. Two facts are striking. First, Pakistan's trade balance declined consistently for almost two decades, i.e., from the early 1980s up to the early 2000s. Indeed, the decline was substantial: the trade deficit stood at 11 percent of GDP during 1980-84 but fell in each of the succeeding five-year periods, virtually disappearing in 2000-04. However, the trend thereafter reversed and the trade deficit started to rise quickly, reaching about 8 percent of GDP in 2005-09. This was at the core of the economic crisis of 2008/09 (see Haque, 2010).

Figure 1: Balance of trade as a percentage of GDP

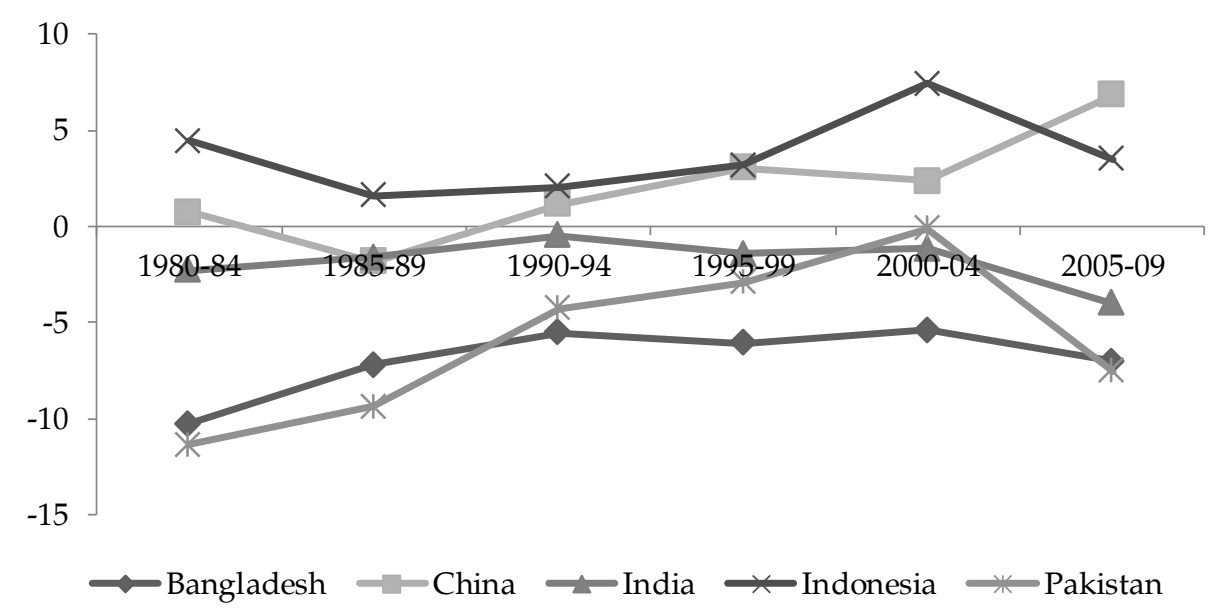

Source: World Bank, World Development Indicators, 2014. 
Second, except for a brief period in the early 2000s, Pakistan ran substantially higher trade deficits in relation to its GDP than India, while China and Indonesia had sizeable trade surpluses. This mirrors Pakistan's notorious savings deficit, where it is not just that savings are low in relation to investment but, more seriously, that they are low in relation to a very low investment rate (Haque \& Amjad, 2012) The country's problem is not just one of financing the trade deficit but also that such financing supports an extremely low investment rate. In other words, it is really noninvestment expenditures that are behind Pakistan's trade deficits. Thus, measures aimed at cutting investment in order to improve macroeconomic imbalances have tended to fail while dampening economic growth. This was amply evident in the aftermath of the 2008 crisis (Haque \& Amjad, 2012).

An examination of export and import trends over the three decades 1980-2009 suggests that, because Pakistani exports varied only a little in relation to GDP, the movement in trade deficits was, by and large, driven by imports (Figures 2 and 3). Pakistan's export ratio hovered around 12 percent during the 1980s but rose to about 17 percent in the first half of the 1990s, before trending downward for more than 15 years. Exports were down to less than 15 percent of GDP in 2004-09. This is in sharp contrast to the performance of all other comparator countries, whose export ratios generally rose, in some cases, sharply.

Figure 2: Exports as a percentage of GDP

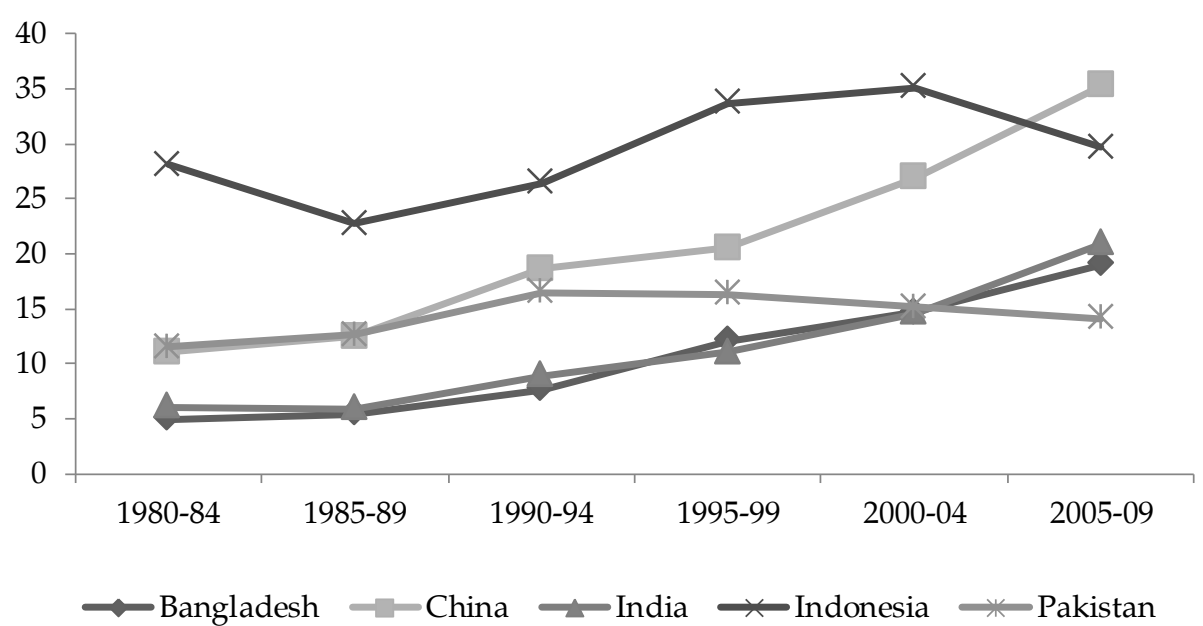

Source: World Bank, World Development Indicators, 2014.

While China's export ratio was about the same as Pakistan's (around 12 percent of GDP) during the 1980s, those of India and 
Bangladesh were less than half (Figure 2). However, each of the other three countries registered a sharp improvement in their export performance, leaving Pakistan well behind. Bangladesh's ratio rose from barely 5 percent in 1980-84 to 19 percent in 2005-09, while India's ratio rose from 6 percent to over 20 percent. China's stellar performance as an exporter is, of course, well known and is evident from the figure: exports now account for more than a third of its GDP. Of the group of countries in the figure, Indonesia appears to be particularly outward-oriented. Although its exports were already high in relation to its GDP in the 1980s (slightly under 30 percent), they continued to rise and reached 35 percent in the early 2000 s.

The behavior of imports, on the other hand, is distinctly different. Imports-as in the case of exports-constituted a much larger proportion of Pakistan's GDP than in the case of Bangladesh, China, or India (Figure 3). During the 1980s, Pakistan's import ratio was practically the same as that of Indonesia. The difference was that, while imports into the latter three countries registered steep increases during the period and more or less tracked the movement in exports, Pakistan's import ratio experienced a substantial decline- from close to 25 percent during the 1980s to a low of 15 percent in 2000-04. In other words, imports rose much faster than GDP in other countries but, in Pakistan, the increase was far slower. However, imports recovered strongly post-2004, causing a dramatic turnaround in the trade balance and culminating in a BOP crisis in 2008/09 (see Haque, 2010).

Figure 3: Imports as a percentage of GDP

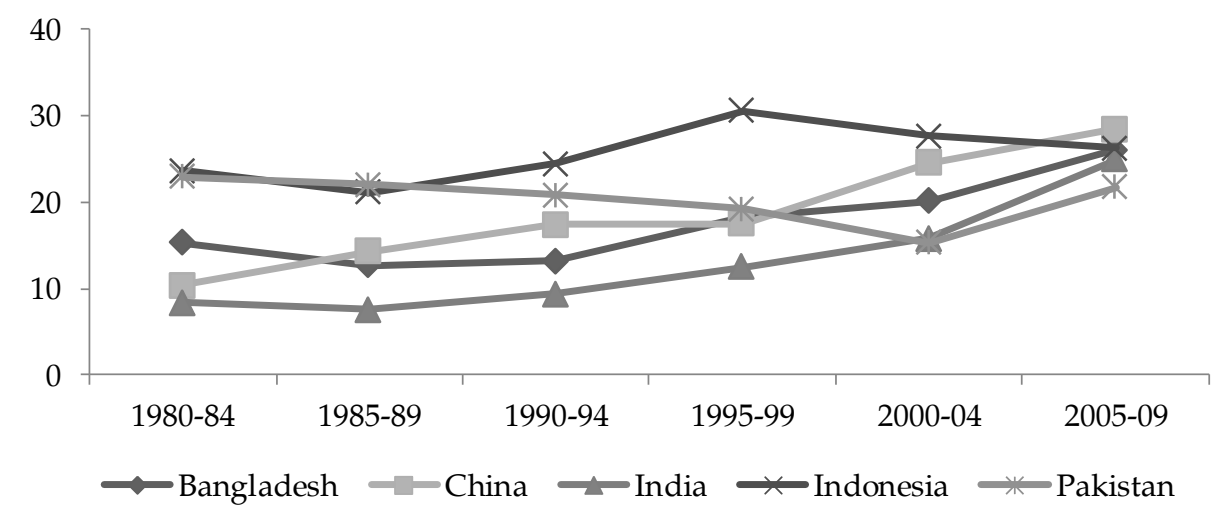

Source: World Bank, World Development Indicators, 2014.

Pakistan's lagging foreign trade performance suggests that, while other countries became more closely integrated with the global economy, the former showed signs of withdrawal. Pakistan's share of world trade is currently under 0.2 percent, considering its share of world GDP (about 0.4 
percent) and world population (over 2.5 percent). Rapidly rising exports permitted Bangladesh, China, and India to sustain higher import levels, but imports into Pakistan remained constrained primarily by foreign resource inflows as foreign exchange reserves even at peak were relatively modest. In the years that the foreign exchange situation was particularly tight-as during the late 1980s and 1990s-imports were sharply compressed. On the other hand, with foreign exchange becoming more plentiful during 2005-08, imports recovered sharply.

This finding suggests that, because foreign resource inflows into Pakistan are, by and large, exogenous (i.e., the country has little control over them), the only way to sustain adequate imports is through export growth. Even during the peak of 2005-09, Pakistan's import ratio was lower than that of any of the other comparator countries. This implies that, far from being exceptionally import-dependent as is commonly believed, the country is import-constrained. Since economic growth and imports are interdependent, relieving the constraint on the latter makes the sustainability of the former more likely. In order for imports to keep pace with future economic expansion, exports must rise sufficiently to keep the trade deficit manageable.

In brief, Pakistan's foreign trade problem is one of lagging export performance combined with surges of imports during periods of rapid economic growth and easier availability of foreign exchange. Imports into Pakistan, as has been the experience of other countries, should be expected to rise more rapidly than the rise in overall demand, which, for a given level of foreign exchange reserves, would necessitate increased reliance on foreign inflows. The common cause of past BOP crises has been insufficient foreign inflows even as the trade deficit widened. The situation is not helped by the fact that Pakistan's savings ratio is abysmally low in comparison to that of other Asian countries. Raising export levels-along with improving the domestic savings rate-must, therefore, be the key goal of macroeconomic policy.

\section{The Pathology of Export Failure}

Pakistan's poor export performance has often been attributed to the structure of its exports, i.e., concentration on a few traditional products, a failure to diversify and move up the value chain, and an absence of domestic technology-intensive industries. ${ }^{2}$ The reasons for this state of

2 A number of studies have addressed the issue of Pakistani exports, notably Ahmed, Mahmud, Hamid, and Rahim (2010), Felipe (2007), Lall and Weiss (2004), Rahim (2012), and the World Bank (2006). 
affairs are diverse but low fixed investment, low skill accumulation, lack of competition, poor infrastructure, and government policy are usually cited though with differing emphasis. However, this list of factors, while comprehensive as a description, does not provide a practical approach to dealing with the problem of poor export growth. The causes identified are generic and would more or less explain the faltering export performance of (say) the US as well as of Pakistan. What is attempted here is to assess the scale of the failure, both in its own terms and in comparison to other countries, and to identify the main source of the problem.

In their seminal study, Imbs and Wacziarg (2003) provide statistical evidence on the long-term relationship between sectoral concentration and per capita income. They show that economies tend to become more diversified as they grow and become richer, but after reaching a certain threshold of income, the sectoral concentration begins to rise. There is, however, no particularly satisfactory explanation for this phenomenon. Imbs and Wacziarg attribute it to two factors: (i) as incomes rise, consumer demand becomes more diversified, leading to more diversified production; and (ii) sectoral diversification allows the spreading of investment risk. The authors, however, acknowledge that "there is no theoretical consensus as to how measures of sectoral diversification should evolve as countries grow, although the force of diversification is probably more at play among low-income countries, and the force of concentration among richer countries" (p. 64).

Ahmed et al. (2010) measure the diversification index for Pakistani exports over 1974-2008 and find that, after hovering around 0.45 until the mid-1980s, product concentration increased until the mid-1990s before trending downward. It fell back to about the same level as during the 1970s. Considering the length of the period covered, the variation in the index is rather small. The authors also note that Pakistan's product concentration is greater than that of Malaysia, Thailand, or India. However, this does not satisfactorily explain Pakistan's poor export performance for two reasons. First, the differences in the countries' indices, while significant, are not large enough to explain the large dissimilarity in intercountry performance in trade. India has the lowest concentration of the countries mentioned but its export performance was significantly worse than that of either Malaysia or Thailand.

Second, the causation could be running in the opposite direction. Rapidly growing economies are associated with higher investment rates, resulting in increasingly diversified production structures. A country with 
a high investment rate can be expected to invest in a broader range of industries than one with a low investment rate. This might also explain why industrial concentration tends to rise after per capita income has reached a certain level, since investment rates in mature industrial economies are seen to decline to low levels in comparison to economies on a rapid growth path.

Although there has been little change in the degree of product concentration in Pakistan, as Ahmed et al. (2010) show, the ranking of the country's leading exports has shifted, albeit modestly, over time. In other words, while there were few new entrants among Pakistan's top exports, some exports became more important than before as other exports yielded ground. Table 1 provides the rank correlation of leading exports (at threedigit SITC) between 1995, 2000, 2005, and 2010. As expected, the rank correlation between closer years is quite high; it declines when the comparison is between more distant years. Thus, the rank correlation between 1995 and 2000 is 0.93 but is 0.64 between 1995 and 2010 . We observe a similar trend when comparing other pairs of years. ${ }^{3}$ Such change in the ranking of exports as occurred, however, did not noticeably affect Pakistan's export performance.

Table 1: Rank correlation estimates for Pakistan's exports*

\begin{tabular}{lccc}
\hline Rank correlation wrt & $\mathbf{2 0 0 0}$ & $\mathbf{2 0 0 5}$ & $\mathbf{2 0 1 0}$ \\
\hline 1995 & 0.93 & 0.75 & 0.61 \\
2000 & & 0.85 & 0.72 \\
2005 & & & 0.82 \\
\hline
\end{tabular}

* Calculated on the basis of export data from the United Nations Commodity Trade Statistics, 2010.

A closely related explanation for Pakistan's poor export performance is the low-technology intensity of its exports. Lall and Weiss (2004) observe that, in contrast to the East Asian economies, Pakistan's medium- and high-technology products occupy a very low share of production and exports. Although the country has moved from primary exports to manufactures over time, textiles and clothing-which are regarded as low-technology products-have a preponderant weight in total exports. The authors note:

${ }^{3}$ Pakistan's industrial structure, however, changed far less, implying that the relative importance of industries remained virtually unchanged. Using the data in Felipe (2007, Table 3), the rank correlation was 0.97 between the 1970s and 1980s, and 0.94 between the 1970 s and 1990s. 
Such concentration is inherently risky, but the nature of the products makes it even less desirable. These are not dynamic activities ... they are among the slowest growing industrial activities in the world. Their export growth is reaching a plateau as the relocation from high to low wage countries matures. They offer limited potential for learning or technological and skill spillovers. They attract relatively little and low value FDI. Its current export structure gives Pakistan a weak competitive base that is unlikely to drive sustained industrial growth (p. 29).

Felipe (2007) has voiced similar concerns. Although the share of Pakistan's top ten exports declined from over 60 percent in 1986 to 50 percent in 2004, nine of these exports consisted of textiles and apparel (p. 21). Drawing on the methodology developed by Hausmann, Hwang, and Rodrik (2005), Felipe measures the weighted average income levels of other countries exporting these products (the so-called PRODY index) and finds that the average declined from about US\$ 5,000 in 1986 to about US\$ 3,500 in 2004. In other words, overall, Pakistan appears to be stuck in exporting products that are exported largely by other low-income countries, suggesting that the possibilities for technological upgrading or improving productivity are more limited.

Traditional and low-technology products, of course, dominate Pakistan's export basket, but whether that is a principal cause of its poor export performance is less obvious. The basic premise of the Hausmann et al. (2005) study is that, the higher the per capita income of the economies with which a country competes, the greater will be the scope for enhancing productivity. Theoretically, this may be so: a T-shirt producer in Pakistan could aspire to producing Dior dresses one day, but whether it happens is contingent on overcoming a host of real-life handicaps and difficulties, not least salesmanship and the self-promotion that characterize the fashion industry. Just because a product is also produced in an advanced country is not a particularly reliable indicator of a low-income country's technological or productivity potential.

Put differently, designer clothes made in France or Italy do not necessarily lay out the path Pakistani garment manufacturers could or should follow or even indicate how and where they might direct their efforts toward raising productivity and becoming competitive. In the context of the garments industry, however, this does not rule out the option for low-income countries of adopting policies and investments to 
utilize their native capabilities and talent in design and art in order to seek out niche markets and raise their value-added. There is already a thriving fashion industry in Pakistan, though it is concentrated mostly in the domestic market.

Nevertheless, it is useful to know which countries Pakistan is competing against in the world market. The indices proposed by Hausmann et al. (2005) — the PRODY and its cousin, the EXPY - provide the weighted average of the income per capita of a country's competitors, but measuring them is complex and data-intensive. The Pakistani data required for such an exercise are, in any case, of doubtful quality (Felipe, 2007). For the present purpose, a simpler approach involving the identification of Pakistan's lead competitors in the world market will suffice. The results of this exercise are given in Table 2, which identifies the top five world suppliers of each of Pakistan's major exports during 2009-12 and gives the weighted average GDP per capita of these countries. 
Table 2: Pakistan's lead competitors

\begin{tabular}{|c|c|c|c|c|c|c|c|}
\hline & $\begin{array}{l}\text { PK leading exports 2009- } \\
12 \text { (average) }\end{array}$ & $\begin{array}{c}\text { Share of } \\
\text { total PK } \\
\text { exports } \\
(\%)\end{array}$ & $\begin{array}{l}\text { PK share } \\
\text { of world } \\
\text { total }(\%)\end{array}$ & PK's main competitors in world market & $\begin{array}{c}\text { Main } \\
\text { competitors' } \\
\text { share of world } \\
\text { market (\%) }\end{array}$ & $\begin{array}{l}\text { Weighted } \\
\text { av. GDP per } \\
\text { capita (US\$) }\end{array}$ & $\begin{array}{r}\text { Ratio to } \\
\text { PK GDP } \\
\text { per capita }\end{array}$ \\
\hline 041 & Wheat, unmilled & 0.8 & 0.4 & US, Canada, Australia, France, Russia & 66.7 & 9,480 & 7.3 \\
\hline 042 & Rice & 9.0 & 9.7 & Thailand, India, Vietnam, US & 76.0 & 1,916 & 1.5 \\
\hline 334 & Petroleum oils, etc. & 3.6 & 0.1 & $\begin{array}{l}\text { Russian Federation, US, Singapore, The } \\
\text { Netherlands, India }\end{array}$ & 41.6 & 6,775 & 5.3 \\
\hline 651 & Textile yarn & 8.2 & 3.8 & China, India, US, Hong Kong, Italy & 47.5 & 3,649 & 2.8 \\
\hline 652 & Cotton fabric, woven & 10.2 & 7.8 & China, Hong Kong, Italy, India & 66.0 & 2,217 & 1.7 \\
\hline 653 & $\begin{array}{l}\text { Fabric, woven (manmade } \\
\text { textile materials) }\end{array}$ & 1.3 & 0.7 & China, Korea, India, Japan, Italy & 57.6 & 2,575 & 2.0 \\
\hline 658 & $\begin{array}{l}\text { Made-up articles of } \\
\text { textiles }\end{array}$ & 14.6 & 7.2 & China, India, Germany, Turkey & 68.5 & 1,536 & 1.2 \\
\hline 661 & Lime, cement, etc. & 2.3 & 2.0 & China, Italy, Turkey, Germany, Spain & 45.5 & 3,579 & 2.8 \\
\hline 841 & Men's or boys' garments & 4.2 & 1.6 & China, Italy, Germany, Hong Kong, Turkey & 54.3 & 3,384 & 2.6 \\
\hline 842 & $\begin{array}{l}\text { Women's or girls' } \\
\text { garments }\end{array}$ & 2.3 & 0.7 & China, Hong Kong, Italy, Germany, India & 58.8 & 3,214 & 2.5 \\
\hline 843 & $\begin{array}{l}\text { Men's or boys' garments, } \\
\text { other }\end{array}$ & 4.0 & 3.7 & China, Hong Kong, India, Cambodia & 64.5 & 1,516 & 1.2 \\
\hline 845 & Apparel, textiles, n.e.s. & 2.3 & 0.4 & China, Hong Kong, Italy, Germany, Turkey & 57.6 & 3,296 & 2.6 \\
\hline 848 & $\begin{array}{l}\text { Apparel, other than textile } \\
\text { fabrics }\end{array}$ & 1.7 & 1.4 & $\begin{array}{l}\text { China, Malaysia, Italy, Hong Kong, } \\
\text { Germany }\end{array}$ & 62.7 & 2,904 & 2.3 \\
\hline 897 & Jewelry & 3.0 & 0.7 & China, India, US, Switzerland, Hong Kong & 57.2 & 4,841 & 3.8 \\
\hline
\end{tabular}

Source: United Nations Commodity Trade Statistics, 2010; UN Data Explorer, 2014. 
The data show that China is Pakistan's leading competitor (11 products), followed by India (nine products), and Germany (five products). The significance of China or India as competitors to Pakistan lies not so much in the differences in per capita income, which are rather small, but in their extraordinarily high growth rates, while Pakistan has fallen behind. Interestingly, Germany-Pakistan's other leading competitor-is also among the more rapidly growing high-income economies.

Leaving aside wheat and petroleum product exports (which are rather idiosyncratic), the weighted average of per capita income of Pakistan's lead competitors is in no case less than its own, but in most cases it is at least twice as high. Since Pakistan's main competitors are rapidly growing economies or have higher per capita incomes, it would appear that there is considerable room for technological catch-up and productivity growth within the existing production structure. It does not matter how important Pakistan's exports are relative to its competitors; what matters is that these countries still compete in those markets. This is not to deny that it would be desirable for Pakistan to produce and export technologically more sophisticated products with a higher value-added, but enhancing the efficiency of its existing industries would greatly help to improve its performance in the world market and should take precedence.

Another weakness that has been underscored by some observers is that a large segment of Pakistani exports faces declining markets. Lall and Weiss (2004) note:

The picture for Pakistan is ... one of weak product positioning within its areas of export specialization. Sustaining rapid export growth with this positioning if world trade continues to follow recent patterns would involve Pakistan raising its market share in declining markets. Since these markets are fiercely competitive and are being liberalized, this would require massive upgrading of production capabilities, quality and marketing relative to competitors. This is possible, of course, but will not be easy (p. 35).

What an economy produces and exports is, of course, consequential for its longer-term growth. Other things being equal, a rapidly growing market opens up opportunities for new entrants while a stagnant market makes it difficult for firms to grow. However, this does not signify that a country is assured success in one case and failure in the other. Success in 
the world market involves a host of things, notably salesmanship, but occasionally also serendipity. ${ }^{4}$ Dynamic markets often arise through the creativity and drive of individual firms that innovate and create new wants (for example, Sony during the 1970s and Apple in more recent times), and come to enjoy the "first-mover advantage." Even industrial country producers face serious hurdles to entering such markets. As noted above, the relevant point for Pakistan is that, even with its present export composition, it has done little to effectively compete in the world market.

Following the methodology employed by Lall and Weiss (2004), Ahmed et al. (2010) revisit the evidence on the relative performance of different categories of Pakistani exports according to their classification as (i) "champions" (where Pakistan's share has increased in markets that expanded more rapidly than overall trade), (ii) "under-achievers" (where Pakistan has underperformed in otherwise rapidly growing markets), (iii) "achievers in adversity" (where Pakistan's share has risen in markets experiencing a relative decline), or (iv) "declining" (where both Pakistan's share and that of the world market has declined). They find that "champions" (products such as rice, surgical instruments, jewelry, and furniture) accounted for about one fourth of Pakistan's exports in 2008, while the share of "achievers in adversity" was 8 percent. In all, therefore, about a third of Pakistani exports increased their share of the world market while two thirds were in expanding markets. Ahmed et al. correctly conclude that Pakistan's export structure appears to be "fairly healthy" (p. 10).

The foregoing discussion suggests that the country's export composition is not the real problem. Nonetheless, like other successful exporters, Pakistan must over time adapt its areas of specialization to market conditions, eagerly seek out opportunities to move up the value chain, and develop the capabilities to produce increasingly technologyintensive exports. The argument that Pakistan would have done better by specializing in a different set of products is a counterfactual, hard to substantiate. Its poor performance in the world market does not appear to have been principally due to industry-specific failures that might not have arisen had Pakistan's industrialization followed a different course. Because developing countries now dominate world trade in manufacturing, the main challenge for an exporter is to compete with other low labor-cost

4 The extraordinary success of Brazil's aircraft manufacturer, Embraer, owes something to luck: it received a large order for aircraft at an air show in France (see United Nations Conference on Trade and Development, 2003). Bangladesh's move into garments manufacturing and export was also somewhat accidental when Korean producers found in it a way to bypass the quota restrictions under the Multi-Fiber Agreement. 
producers and learn from their experience in bringing about incremental efficiency improvements. This is terrain where countries do not quite reach the level of "best practice" as much as approach it through gradual and sustained improvements in products and processes. In this respect, Pakistan's poor performance in the world market reflects primarily its generally deficient competitiveness.

Apart from quality considerations, a country's competitiveness depends on its direct labor cost and the costs associated with physical infrastructure (transport, power supply, etc.) as well as on the general business environment (regulations, governance, etc.). Pakistan is notorious for its poor infrastructure, especially for the power shortages that have become progressively worse. With supplies unpredictable and plants operating far below capacity due to the lack of natural gas and frequent power outages, industrial efficiency has suffered seriously while production costs have risen. The state of road transportation and portsnever good-has also deteriorated and added to producers' woes.

Taking into account the costs associated with its poor physical infrastructure leaves Pakistan with an enormous competitive disadvantage in the world market. The World Bank (2006) has compared the manufacturing cost of a pair of jeans in Pakistan and certain other countries in 2005 (that is, when the situation was not as dire as it is today). The wage cost in Pakistan is found to be just 60 percent of China's but the former's much lower productivity and higher cost of assembly still give China an enormous cost advantage in the world market. The study also shows that Pakistan faces a serious cost disadvantage vis-à-vis China in the US market on account of higher transportation costs. While these are all serious handicaps that need to be overcome, they still do not quite explain why Pakistani exports continue to lose ground in the world market. The acute power shortage is a relatively recent phenomenon while the country's poor export performance has a long history. The state of physical infrastructure in Bangladesh or India is nothing to boast about, but their exports have performed far better than Pakistan's.

With respect to the general business environment, Pakistan's reputation is poor both within and outside the country. However, the World Bank's Doing Business reports, notwithstanding their many weaknesses, offer a rather more nuanced picture. Over the years, they have consistently placed Pakistan above other Asian exporters, including China, in terms of some criteria. Table 3 gives Pakistan's position vis-à-vis Bangladesh, China, India, and Indonesia in terms of three indicators: the 
"ease of doing business," the average number of days it takes to export, and the average container costs of shipping. In terms of ease of doing business, Pakistan ranks above all others except China, while it takes the same number of days to export in Pakistan as it does in China (21 days). India and Indonesia, however, take far less time to export (Table 3).

With regard to the cost per container, Pakistan's position is again not very different from that of China or Indonesia, but far superior to India or Bangladesh (about 60 percent of their estimated cost). ${ }^{5}$ Clearly, Pakistan must do a great deal to improve the current state of affairs-especially in areas where it lags behind-but the business environment per se does not offer an adequate explanation for the country's poor export performance.

Table 3: Doing business: Selected indices

\begin{tabular}{lccccc}
\hline Indicator & Pakistan & B'desh & China & India & Indonesia \\
\hline Ease of doing business (rank) & 110 & 130 & 96 & 134 & 120 \\
Time to export (no. of days) & 21 & 25 & 21 & 16 & 17 \\
Cost to export (US\$ per container) & 660 & 1,075 & 620 & 1,170 & 615 \\
\hline
\end{tabular}

Source: World Bank (2013a).

The direct labor cost in production is a composite of wages paid and the labor input per unit of output, i.e., the inverse of labor productivity. The data on wages in Pakistan are not systematically collected and are unreliable. Nevertheless, Irfan (2009) has compiled such data on wages as are available for Pakistan, which include a sectoral as well as gender breakdown. Figure 4 describes the movement in real wages in manufacturing covering the years 1990/91 to 2006/07 and the wage movement in terms of US dollars, i.e., the nominal wage index discounted by the nominal exchange rate index.

For most of this period, the two indices track each other closely, which suggests that the exchange rate was kept broadly in line with domestic inflation. Taking the period as a whole, real wages hardly increased between the mid-1990s and mid-2000s, although there was a substantial decline up till the early 2000s and a sharp recovery thereafter. When wages are adjusted for the exchange rate, the pattern remains broadly the same, although the wage recovery is stronger in the latter

5 According to Transparency International's (2013) Global Corruption Barometer, the incidence of bribery in Pakistan is estimated at 34 percent while that of India is 54 percent. This is not meant to suggest that corruption is not a serious problem in Pakistan, but instead that it is probably not a leading cause of its economic failures. 
period. It is possible that there was some erosion of competitiveness during the 2000s, but the data do not go beyond 2006. However, any further significant loss in competitiveness in subsequent years seems unlikely, since real wages probably remained depressed because of the faltering economic activity while the rupee underwent a substantial depreciation during the 2008 economic crisis.

\section{Figure 4: Wages in Pakistan's manufacturing}

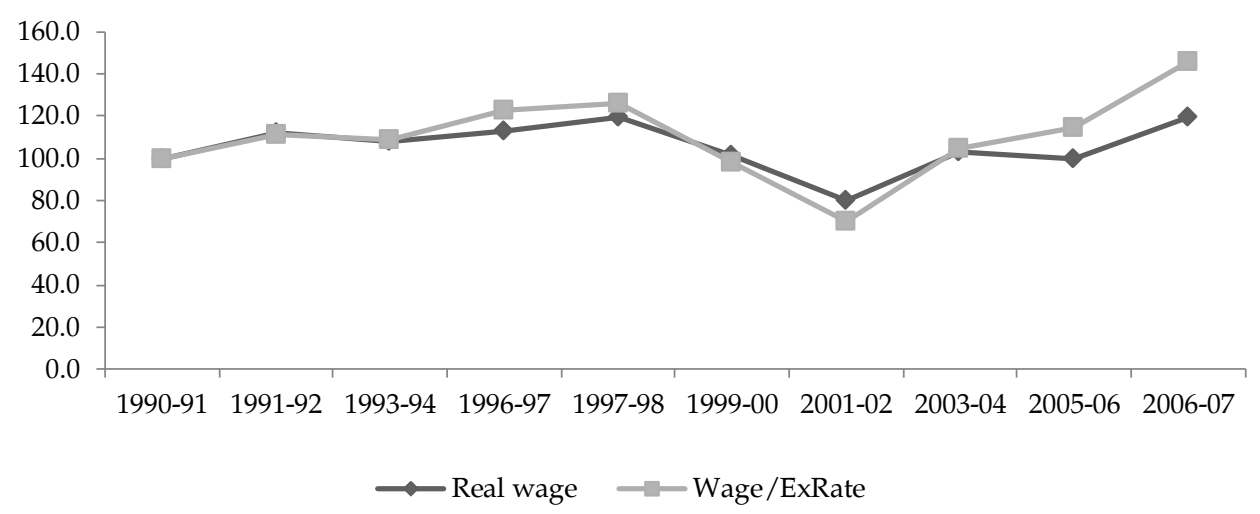

Note: The data for real wages are taken from Table 2 in Irfan (2009).

The principal source of Pakistan's lack of competitiveness, therefore, comes down to its dismal productivity growth. Table 4 provides data on productivity growth for a number of Asian economies over the past decade. In terms of overall productivity, Pakistan registered the lowest growth of all economies during 2000-11: just a little over 1 percent a year in contrast to China's 10 percent and India's 8 percent. With respect to productivity in manufacturing, Pakistan's performance at 2.3 percent, while not at the very bottom, is among the weakest performers. 
Table 4: Productivity growth (annual \%)

\begin{tabular}{lcccc}
\hline & \multicolumn{3}{c}{ Overall } & Manufacturing \\
\cline { 2 - 5 } Country & $\mathbf{2 0 0 0 - 0 5}$ & $\mathbf{2 0 0 5 - 1 1}$ & $\mathbf{2 0 0 0 - 1 1}$ & $\mathbf{2 0 0 0 - 1 0}$ \\
\hline Bangladesh & 1.9 & 3.0 & 2.4 & 1.3 \\
India & 3.5 & 7.7 & 5.6 & 3.4 \\
Indonesia & 3.6 & 2.8 & 3.2 & 2.5 \\
Rep. of Korea & 2.9 & 3.0 & 3.0 & 6.8 \\
Malaysia & 3.0 & 1.0 & 2.0 & 4.2 \\
Pakistan & 2.0 & 0.4 & 1.2 & 2.3 \\
Singapore & 3.1 & 0.4 & 1.8 & 3.9 \\
Sri Lanka & 2.5 & 4.9 & 3.7 & 2.4 \\
Thailand & 3.0 & 2.1 & 2.5 & 4.0 \\
China & 8.6 & 10.2 & 9.4 & 8.0 \\
\hline
\end{tabular}

Note: Average annual growth rate of GDP at constant basic prices per worker, using 2005 purchasing power parity.

Source: Asian Productivity Organization (2013).

Sectoral productivity growth data are generally weak and particularly hard to access for some major developing countries, notably for China and India. Figure 5 compares Pakistan's manufacturing productivity growth with that of Indonesia, Malaysia, and Sri Lanka during 1990-2007. It shows that, as early as 1990, Pakistan's productivity in manufacturing was half that of Indonesia and one fourth that of Malaysia; this gap has widened considerably over time, especially with respect to Malaysia. In 2007, Malaysia was more than ten times as productive and Indonesia three times as productive as Pakistan. Sri Lanka's productivity growth was quite volatile, but its overall performance was not too different to Pakistan's. Far from catching up, these two laggards fell far behind the other economies.

Figure 5: Productivity performance of selected countries

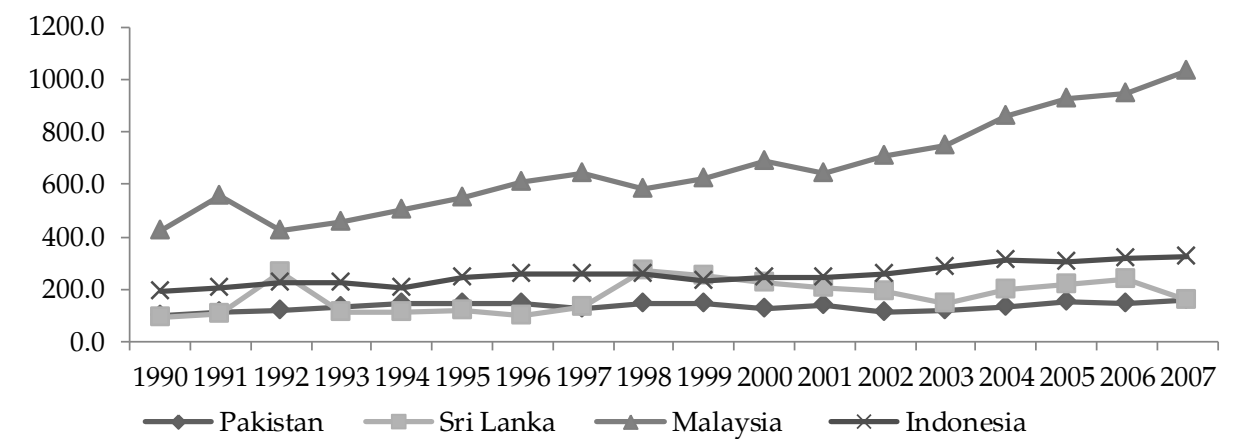

Source: United Nations Statistics Division, National Accounts Estimates of Main Aggregates, 2014. 
What explains this performance? While a number of factors could be held responsible for low productivity in Pakistan's case-power availability, other infrastructure weaknesses, and not least the security situation-extremely low investment in fixed as well as human capital must be considered the heart of the problem. This is confirmed by many studies relating to Pakistan's economic performance (Haque \& Amjad, 2012). With an investment rate of barely 15 percent of GDP, Pakistan ranks among the world's lowest investors. This means that its capital stock is, on the whole, much older than that of its competitors and becoming increasingly so. If we assume a capital-GDP ratio of roughly 3 and an average lifespan of physical assets of 20 years, then no more than a fifth of Pakistan's capital stock is five years old or less. The same for India, which has been investing more than 30 percent of its GDP, is probably in the vicinity of one third. The ratio for China, with much higher investment rates, could be expected to be far higher.

In brief, Pakistan's competitiveness disadvantagenotwithstanding certain industry-specific problems-emanates largely from its generally low and slow-growing productivity. The key to competitiveness is for the economy to become more productive and efficient. Were it to succeed, Pakistan would begin to overcome some of the other identified handicaps (product concentration, its position in the value chain and, not least, the lack of technology-intensive industries) with time. The factors behind its productivity performance are responsible for the generally poor and variable quality of its exports. They also hold back progress in agriculture and trade in services, where the quality and reliability of supply is often even more important. It is, therefore, urgent to alter the current state of affairs as the economy is operating far below its potential and continues to fall further behind other Asian economies. For this to happen, making a concerted effort along the lines adopted by other successful economies will be essential.

\section{Industrial Policy for International Competitiveness}

International competitiveness and industrial policy are
controversial subjects. Paul Krugman dismissed international
competitiveness as a "dangerous obsession" two decades ago, arguing that,
while a firm's competitiveness could be defined, the term had little
meaning in relation to an individual economy. The comparative advantage


doctrine had established that each economy was competitive and could always successfully trade in at least something6 (Krugman, 1994).

With respect to industrial policy, on the other hand, economists grant that policy intervention may be required to address market failures arising from information asymmetries, scale economies, or externalities. Markets also fail when investment decisions involve longer-term considerations or are interdependent and require coordination when investment in one industry is contingent on (say) a road or a power plant being built. However, mainstream economists warn that policy interventions could do more harm than good because of administrative incompetence, corruption, wrong incentives, and other so-called "government failures."

In practice, however, industrial policy remains an instrument of choice even in countries that are otherwise loath to activist government. With the weakening of the "Washington Consensus," its credibility has, if anything, increased. Rodrik (2004) observes: "The reality is that industrial policies have run rampant during the last two decades-and nowhere more so than in those economies that have steadfastly adopted the agenda of orthodox reform" (p. 29).

It was the East Asian economies, however, that demonstrated how industrial policy could be effectively employed to accelerate growth and gain in international competitiveness. All countries, of course, attempt to promote or regulate industry, but these are mostly ad hoc measures aimed at specific concerns pressed upon by different interest groups, whether businesses, labor unions, or regional politics. Where the Asian success stories differ, however, is in their policies forming an essential component of national development programs aimed at achieving accelerated economic growth.

It is not possible or desirable to mimic the approaches adopted by those economies, for Pakistan's "initial conditions" differ and the world trading environment has evolved over time. Nevertheless, their experience affords lessons on which Pakistan could usefully draw, the most important being that the country must, before all else, agree on the general direction of its industrialization. This is as much a political as an economic exercise, requiring consultation and consensus building among stakeholders. What policies are adopted and which industries or businesses are promoted is

${ }^{6}$ With time, Dr Krugman has become politically more progressive (certainly in his columns in the New York Times). Perhaps his views on international competitiveness have also become more moderate. 
inevitably a difficult and uncertain process, but the more egregious mistakes are less likely under a collaborative and transparent process. Rodrik (2004) underscores the "need to embed private initiative in a framework of public action that encourages restructuring, diversification, and technological dynamism beyond what market forces on their own would generate" (p. 3). Neither government bureaucrats unfamiliar with industry nor individual investors with short-term horizons can be trusted to make the right choices regarding investments for long-term sustainable economic growth.

The process of consultation and consensus building is, however, particularly arduous, even risky, in nascent democracies where the "fundamentals" still wait to be worked out. An influential section of Pakistan's professional opinion is skeptical about interfering with the market and assigning state influence in domains where its competence is suspect. Thus, the vision of the Planning Commission's economists of industrial development has been at odds with that of the Ministry of Industry and Production (Hussain \& Ahmed, 2011). The East Asian economies, under dictatorships or virtual dictatorships, arguably enjoyed a certain advantage in defining their national economic goals and devising interventionist policies in pursuit of these goals during their early industrialization.

Naseemullah and Arnold (2012) identify the absence of "developmental state persistence" as an important reason that Pakistan has failed to emerge as a strong, competitive economy-a goal that seemed within its reach back in the 1960s when it compared rather favorably with the Republic of Korea or Taiwan. The commitment to the "developmental state" waned, in the first instance due to the wholesale nationalization of industry under Zulfikar Ali Bhutto in the 1970s, which was undertaken without much planning or thought or even ideological commitment. However, before the economy could recover from this shock, the 1980s witnessed the rise of a neoliberal ideology that insisted on free markets, trade liberalization, deregulation, and privatization. The economics profession-but more importantly, the international financial institutionsembraced this ideology without question or demur and started to push it on the developing world under the rubric of "structural adjustment." Pakistan, too, came under its sway and the government's role in economic development remains contested territory to this day.

The conventional wisdom maintains that, for exports to grow, it is necessary to remove the "bias" against them. Recommendations to that 
end typically include trade liberalization, exchange rate depreciation, deregulation, and a general opening up of the economy (Pakistan, Planning Commission, 2008; Hussain \& Ahmad, 2011; Pursell, Khan, \& Gulzar, 2011). There is little evidence to suggest, however, that such measures by themselves caused the rapid economic growth in Asia or that they would have on their own helped Pakistan turn its fortunes around (Haque, 2004, 2009).

Pakistan is a relatively open economy. Although, like other developing economies, it has nurtured and protected domestic industry, import barriers have come down over time. Its present level of protection (when nontariff barriers [NTBs] are also taken into account) compares well with other developing economies, including those that have grown rapidly in recent years, notably China and India. ${ }^{7}$ But this has not brought about the promised gains in productive efficiency or resulted in much diversification of exports. It is doubtful that further liberalization should be the country's top priority at this juncture, although there is an obvious need to rationalize protectionist policies and eliminate import barriers and regulations that are redundant or inefficient.

Pursell et al. (2011) identify a number of areas where Pakistan's trade policy could usefully be re-examined. Such policy reforms need to be cast in the context of a coherent, articulated industrial policy specifically aimed at improving the country's economic performance. In devising a program of reform, taking into consideration today's realities and exigencies will be paramount. What countries could do to promote economic growth and development 20 or 30 years ago is now no longer feasible or practical.

Indeed, the profound changes in the world trading order over the past two decades call for a fundamental rethinking of industrial policy. Foremost among these developments is the loss of relevance of the textbook model that explained trade and specialization between a developing country and the high-income industrialized world in terms of countries' factor endowment. Today, Pakistan's wellbeing is threatened

\footnotetext{
7 The state's role in China is well established, but India is no exception. According to the World Bank (2013b): “Although India has steadily opened up its economy, its tariffs continue to be high when compared with other countries, and its investment norms are still restrictive. This leads some to see India as a 'rapid globalizer' while others still see it as a 'highly protectionist' economy." Also: "India however retains its right to protect when need arises. Agricultural tariffs average between 30-40 percent, anti-dumping measures have been liberally used to protect trade, and the country is among the few in the world that continue to ban foreign investment in retail trade. Although this policy has been somewhat relaxed recently, it remains considerably restrictive."
} 
more by competition from other low-cost producers with broadly similar factor endowments than from industrialized countries. The impact of this relatively new source of competition is felt in export markets as well as in its own domestic economy. Chinese imports have effectively replaced imports from the industrialized countries and, more importantly, severely hurt some segments of the domestic industry.

This competition has done little to push Pakistan's industry to become more efficient, and there is little chance of this happening in the future. The fact is that its new competitors are much larger and are actively supported by their own governments even as they continue to invest evergreater amounts in upgrading physical and human capital. They also have the financial muscle to acquire foreign firms, pursue research and development (R\&D), and promote sales in overseas markets. Pakistan, in all these respects, finds itself at a considerable disadvantage.

The corollary is that the dismissal of import substitution policies on the grounds that they violate the comparative advantage has lost any merit it ever had. A good portion of Pakistan's imports now consist simply of products that were once produced or could possibly be produced domestically under proper circumstances-demonstrating successful import substitution on the part of its new competitors. If import substitution worked for them, it should in principle work also for Pakistan. Their success confirms that the comparative advantage is not something endowed to a country but created (or lost). Unfortunately, Pakistan did not respond to the new source of competition with the required vigor, foresight, and nimbleness, but accepted passively the new trade winds. The consequence was that it lost ground to other suppliers that could possibly have been retained, but would now be difficult to recapture.

A related development is that it is no longer sufficient to be a lowcost producer. In order to be able to sell in the world market, the producer is required to become part of a trade network or value chain. As the Asian Development Bank (2003) has observed: "Explaining how and where a manufactured good is 'produced' is no longer an easy matter-design, production, distribution, and servicing are all divided into elements that are spread all over the world" (p. 211). Thus, the "outward-oriented" strategies based on low wages (pursued, for example, by the Republic of Korea or Taiwan in their early industrialization) are unlikely to be as effective in today's environment. 
This suggests that what Pakistan needs to be concerned about is not its "comparative advantage" (whatever that may mean) but its "absolute advantage." In other words, it will successfully compete against such countries as China or India only by ensuring that domestic producers are more productive and efficient and at least as good in quality. This will not be possible, however, by merely letting the market do its magic: it requires a vast increase in investment in physical capital and skills development.

Indeed, active and concerted government intervention is required to persuade, help, and support domestic industry toward that end. Profit maximization (or cost minimization) in standard economics textbooks is indifferent to the means adopted for its realization, but the means do matter. It is one thing to maximize profits by compressing wages (e.g., by means of a currency devaluation) and quite another to do so through deliberate measures to enhance productivity. Factory owners or managers do not seek to maximize profits in a literal sense, but rather use it to guide their decision-making (Nelson \& Pack, 1998).

Central to a strategy for gaining international competitiveness, therefore, is a concerted effort to raise Pakistan's investment rate to a level comparable to other Asian economies (perhaps a minimum target of 30 percent of GDP could be set), while fostering entrepreneurship, creativity, and innovativeness in the private sector. The latter involves policies and institutions that promote learning and technological adaptation in industry. This is the real challenge. In the context of Pakistan, Lall and Weiss (2004) note:

By its nature, it is very difficult to measure technological effort in practice. It is clear from official statements that the Government of Pakistan has recognized fully the need for increasing local technological effort. However, per capita R\&D spending in Pakistan is among the lowest for all countries for which data is available, and enterprisefinanced R\&D is negligible. Other indicators, such as number of scientists engaged in $R \& D$ per million inhabitants, number of technicians in $R \& D$, number of scientific and technical journals per million inhabitants, and royalty and technical fees per capita, also highlight the lag that Pakistan suffers with respect to its comparators in the region (p. xix). 
This leads to another important element of the new approach to industrial policy. What Pakistan needs at this stage is not so much promotional policies for specific industries-since the lack of competitiveness is pervasive in industry-as devising a program to significantly improve firm-level performance. A country's competitiveness depends ultimately on the global performance of its business firms, which are the principal agents of technological change. It is their investment in machines and skill upgrading as well as innovation (bringing to the market new products at lower cost) that determine the growth in their sales and profits. Thus, the performance of individual firms-be it Toyota in Japan, Huawei in China, or Tata in India-determines whether a country is positioned to catch up with the industrially more advanced economies. Unfortunately, Pakistani firms have generally performed poorly in all these respects, with a few notable exceptions that give cause for hope and could provide guidance on what other firms must do (Sender, 2013).

Competitive pressure might induce firms to take steps to reduce costs and improve quality, but that is seldom enough, especially when the entire economy is trapped in a malaise, as is the case in Pakistan. Government action and intervention is then required to set things in motion. Again, this is an area where the East Asian experience offers useful guidelines on how a government might reward or punish firms depending on their performance against established and transparent criteria. The Korean government, during the early phase of the country's industrialization, relied on agreed performance targets that firms had to fulfill to qualify for various incentives on offer, notably for subsidized credit. However, the most pressing handicap to Pakistani industry just now is the acute power shortage, which has raised production costs and made supplies unreliable. Unless this bottleneck is removed, there is little hope of Pakistani firms gaining competitiveness. Resolving the energy crisis must, therefore, be made the topmost priority - even a precondition-in the new industrial policy.

Finally, the design of industrial policy must take into account the rules that govern world trade, which have over time become more stringent and are being more strictly enforced. The so-called "policy space" for Pakistan, as for other developing countries, has shrunk greatly since conventional protectionist measures are no longer permitted under the World Trade Organization (WTO) regime. At the same time, with the rise of complex and crisscrossing preferential trading arrangements, the mostfavored nation (MFN) clause has become increasingly irrelevant. 
The MFN principle disallowed discriminatory tariffs and trade preferences and was the cornerstone of the postwar multilateral trading system. This development is particularly threatening to Pakistan, which is neither a large enough economy to attract the interest of the US or the European Union (EU) as a bilateral preferential trading partner nor is it a least-developed economy that might qualify for preferential treatment under the General Scheme of Preferences (GSP) (Haque, 2009). The EU has, however, recently granted Pakistan (on an exceptional basis) GSP-plus status under which some 20 percent of the latter's exports will enter the EU duty-free and 70 percent at preferential rates. This will help Pakistan but it is too early to tell its actual economic significance.

Pakistan's Ministry of Commerce lists a number of bilateral trade agreements on its website, including those with Sri Lanka, Malaysia, China, and Iran as well as a multilateral agreement among the SAARC members, i.e., the South Asian Free Trade Area (SAFTA). The free trade agreement (FTA) with China, which was signed in 2006, is by far the most significant. It provided for China to eliminate tariffs on 35.5 percent of its imports from Pakistan within three years and on another 34.5 percent within five years, bringing the total to 70 percent of imports. On its part, Pakistan undertook to eliminate tariffs on 35.6 percent of its imports from China within three years and on a further 19.9 percent within five years.

The agreement's actual implementation and benefits to Pakistan have not so far been evaluated, but the country's trade deficit with China has risen rapidly and currently stands at about US\$ 10 billion. This situation is clearly unsustainable and calls for action to bring the deficit down. The true significance of the FTA with China goes beyond trade and lies in the development of closer economic and political ties with a large, rapidly growing economy; this potential, however, remains untapped. Any serious strategy for Pakistan's industrialization must seek to exploit this potential, especially in the sphere of technological upgrading.

Segments of Pakistan's business community and official circles are eager to normalize commercial relations with India, but serious hurdles remain. Trade between the two countries has, nevertheless, grown rapidly over the past decade and, despite Pakistan continuing to withhold the extension of MFN status to India, the trade deficit with India now exceeds US\$ 3 billion. The reality is that trade between the two countries is governed not so much by the height of the tariffs as by NTBs, a domain where India has been particularly astute. 
Given India's importance as a trading partner, Pakistan's ability to compete would depend critically on how "normal commercial relations" come to be defined between the two countries. Rather than debating the MFN issue (which has little economic significance for either country), it would probably be more useful to seek a bilateral trading arrangement based on strict reciprocity, where the costs and benefits for both countries are appropriately balanced. Given the disparities in firm size and the technological edge Indian firms enjoy vis-à-vis Pakistan, trade between the two countries cannot just be ignored or left for the market to work out, as some suggest, but should be made a key element in defining a new industrial policy for Pakistan.

\section{Conclusions}

The paper has developed a case for a concerted effort, initiated and pursued by the government, to improve Pakistan's performance in the global economy. Unlike some of the more rapidly growing Asian economies, Pakistan has come to lag behind in terms of virtually every economic indicator and its role and place in the global economy remains quite insignificant. For the size of its economy, it is clearly punching well below its weight in the world market.

We have reviewed the reasons generally offered to explain the country's unsatisfactory export performance, but found them wanting in one or another respect. It is factually accurate that Pakistan's exports are concentrated in a few products with low value-added. Compared to the East Asian economies, the technology intensity of its industry and exports is also quite low. The paper has also examined the previous prognoses of the export sector, but found little to assure that Pakistan's export performance would improve by simply promoting new industries and exports. In other words, while the description of the problem is correct, the reasons proffered for the country's export failure are less than convincing. Nor have we found in the present sorry state of its physical infrastructure a satisfactory explanation for Pakistan's poor performance in the world market.

Our own assessment is that Pakistan's problem is fundamentally one of pervasive low labor productivity in industry compared to its competitors in the world market. This state of affairs is unlikely to be remedied through such conventional measures as exchange rate adjustment, trade liberalization, privatization, or deregulation, which are often put forward. What seems to be required is a national commitment to improving Pakistan's competitiveness in the world market through a coherent 
industrial policy. The minimum goal must be not to let Pakistan fall further behind its main competitors-which are now mostly other low-income economies-in terms of productivity, technology, and general efficiency. As shown in the paper, the productivity gap between Pakistan and some other Asian economies is wide and increasing rapidly. Rather than proposing a set of specific policies, the paper has highlighted certain elements that should underpin the design of a new industrial policy. These elements are:

- The definition of a new industrial policy should be viewed as a political rather than an economic or technocratic exercise. For the policy to be taken seriously and implemented assiduously as a national action program, it must have the support of at least the principal stakeholder, i.e., the private sector.

- The new industrial policy must recognize and be based on the fundamental change in the pattern of international trade that has occurred over the past several decades, i.e., the emergence of some developing countries as dominant world suppliers of manufactured goods. This is indicative of a change in the basis of specialization in world trade from one of "comparative advantage" derived from cheap labor to one based on deliberate, policy-supported enhancement in the "absolute advantage." By making a concerted effort, Pakistan could expect both to become internationally competitive and to bring about a sustained increase over time in its living standards. For this to happen, it is vital that Pakistan's investment rate (and, therefore, savings rate) as well as expenditure on skills upgrading and innovation is substantially raised. This calls for a fundamental rethink in the approach to competition in the world market, from one of short-term cost-cutting measures (as, for example, currency depreciation) to one targeted at improving productivity and product quality.

- However, since the principal agents of technological change are business firms, the new strategy should focus on the performance of Pakistani firms in the world market rather than promoting individual industries. This shift in focus is also warranted because, as noted, Pakistan's competitive weakness is not industry-specific but pervades virtually all sectors. The government's role would lie in instituting a system of incentives and penalties that encourages firms to take a longer-term view in their investment decisions and foster a spirit of entrepreneurship, creativity, and innovativeness. How this is to be done is at the heart of the new industrial policy and will obviously require the private sector's involvement in working out the process. 
- Finally, the new industrial strategy must take into account the changed international trading environment where, on the one hand, WTO rules are being more strictly enforced, but on the other, preferential trading agreements have greatly compromised the notion of MFN status, the guiding principle of the world trading system. This has given rise to ad hoc and reciprocal preferential trading arrangements spearheaded by the US and EU, from which Pakistan is excluded and has little likelihood of being included. Pakistan needs to find ways of taking fuller advantage of its bilateral trade agreement with China and to ensure that its long-term commercial interests are protected as it opens up to trade with India. Extending MFN treatment to India is not really the issue and Pakistan could remove this hurdle without any cost to itself. What is, however, required is that the "normalization" of trade relations be strictly based on the principle of reciprocity, particularly with respect to NTBs. 


\section{References}

Ahmed, H., Mahmud, M., Hamid, N., \& Rahim, T. (2010). A strategy for reversing Pakistan's dismal export performance (Policy Paper No. 01-10). Lahore, Pakistan: Centre for Research in Economics and Business.

Asian Development Bank. (2003). Asian development outlook 2003: Competitiveness in developing Asia. Manila: Author.

Asian Productivity Organization. (2013). APO productivity databook 2013. Tokyo, Author.

Felipe, J. (2007). A note on competitiveness and structural transformation in Pakistan. Manila: Asian Development Bank.

Haque, I. (2007). Rethinking industrial policy (Discussion Paper No. 183). Geneva: United Nations Conference on Trade and Development.

Haque, I. (2009). The rise of bilateralism in trade and its implications for Pakistan [Special edition]. Lahore Journal of Economics, 14, 111-133.

Haque, I. (2010). Pakistan: Causes and management of the 2008 economic crisis (Global Economy Series No. 22). Penang, Malaysia: Third World Network.

Haque, I., \& Amjad, S. (2012). Toward a heterodox approach: Reconciling stabilization and economic growth in Pakistan [Special edition]. Lahore Journal of Economics, 17, 1-32.

Hausmann, R., Hwang, J., \& Rodrik, D. (2005). What you export matters (Working Paper No. 11905). Cambridge, MA: National Bureau of Economic Research.

Hussain, S. S., \& Ahmed, V. (2011). Experiments with industrial policy: The case of Pakistan (Working Paper No. 124). Islamabad: Sustainable Development Policy Institute.

Imbs, J., \& Wacziarg, R. (2003). Stages of diversification. American Economic Review, 93(1), 63-86.

Irfan, M. (2009). Pakistan's wage structure during 1990/91-2006/07 (Working Paper No. 2009: 54). Islamabad: Pakistan Institute of Development Economics. 
Krugman, P. (1994). Competitiveness: A dangerous obsession. Foreign Affairs, 73(2), 28-44.

Lall, S., \& Weiss, J. (2004). Industrial competitiveness: The challenge for Pakistan (Seminar paper). Islamabad: Asian Development Bank.

Naseemullah, A., \& Arnold, C. E. (2012). The politics of developmental state persistence: Institutional origins, industrialization and agrarian challenge (Mimeo). London: London School of Economics and Political Science.

Nelson, R. R., \& Pack, H. (1998). The Asian miracle and modern growth theory (Policy Research Working Paper No. 1881). Washington, DC: World Bank.

Pakistan, Planning Commission. (2008). Economic stabilization with a human face. Islamabad: Author.

Pursell, G., Khan, A., \& Gulzar, S. (2011). Pakistan's trade policies: Future directions (Working Paper 11/0361). London: International Growth Centre.

Rahim, S. (2012). Industrialization by fitting in: Acquiring technology through collaboration and subcontracting [Special edition]. Lahore Journal of Economics, 17, 83-102.

Rodrik, D. (2004). Industrial policy for the twenty-first century (Faculty Research Working Paper No. 04-047). Cambridge, MA: Harvard University.

Sender, H. (2013, November 19). Pakistan's world-class businesses held back by energy crisis. Financial Times. Retrieved http://www.ft.com/cms/s/0/bb0ce230-50f9-11e3-b49900144feabdc0.html\#axzz39zsHIxpm

Transparency International. (2013). Global corruption barometer 2013. Berlin: Author.

United Nations Conference on Trade and Development. (2003). Transfer of technology for successful integration into the global economy (Report No. UNCTAD/ITE/IPC/2003/6). Geneva: Author. 
United Nations Statistics Division. (2010). UN commodity trade statistics [Database]. Retrieved from http://comtrade.un.org

United Nations Statistics Division. (2014a). National accounts estimates of main aggregates [Database]. Retrieved from https: / / unstats.un.org/unsd/snaama/Introduction.asp

United Nations Statistics Division. (2014b). UN data [Database]. Retrieved from http://data.un.org/Explorer.aspx

World Bank. (2006). Pakistan: Growth and export competitiveness (Report No. 35499-PK). Washington, DC: Author.

World Bank. (2013a). Doing business 2014: Understanding regulations for small and medium-size enterprises. Washington, DC: Author.

World Bank. (2013b). India: Foreign trade policy [Web page]. Retrieved from

http:/ /web.worldbank.org/WBSITE/EXTERNAL/COUNTRIES/ SOUTHASIAEX...:579454 pagePK:34004173 piPK:34003707 theSi tePK:579448,00.html

World Bank. (2014). World development indicators [Database]. Retrieved from http://data.worldbank.org/data-catalog/worlddevelopment-indicators. 